\title{
INFLUENCE OF ARBUSCULAR MYCORRHIZAL FUNGI AND Pseudomonas fluorescens AT DIFFERENT SUPERPHOSPHATE LEVELS ON LINSEED (Linum usitatissimum L.) GROWTH RESPONSE
}

\author{
Neetu Neetu ${ }^{1}$, Ashok Aggarwal ${ }^{1 *}$, Anju Tanwar ${ }^{1}$, and Alpa Alpa ${ }^{1}$
}

\begin{abstract}
The aim of this study was to investigate the influence of arbuscular mycorrhizal fungi (AMF) Glomus mosseae (T.H. Nicolson \& Gerd.) Gerd. \& Trappe and Acaulospora laevis (Gerd. \& Trappe) on linseed (Linum usitatissimum L.) growth response with phosphate solubilizing bacteria Pseudomonas fluorescens; different doses of superphosphate were used: 20 $\mathrm{kg} \mathrm{ha}^{-1}$ (half recommended dose), $40 \mathrm{~kg} \mathrm{ha}^{-1}$ (recommended dose), and $80 \mathrm{~kg} \mathrm{ha}^{-1}$ (double recommended dose) in earthen pots filled with sterilized soil under greenhouse conditions. Among all the growth parameters, the following were the highest in the G. mosseae $+P$. fluorescens combination at the medium concentration (recommended superphosphate dose): plant height $(78.74 \pm 1.8 \mathrm{~cm})$, fresh shoot weight $(3.45 \pm 0.294 \mathrm{~g})$, dry shoot weight $(0.57 \pm 0.007 \mathrm{~g})$, fresh root weight $(0.223 \pm 0.023 \mathrm{~g})$, dry root weight $(0.036 \pm 0.004 \mathrm{~g})$, root length $(17.67 \pm 0.48 \mathrm{~cm})$, AM spore number $(94.4 \pm 9.86)$, shoot $(1.14 \pm 0.115 \%)$ and root $(1.29 \pm 0.110 \%) \mathrm{P}$ content, and acidic $\left(0.447 \pm 0.012 \mathrm{IU} \mathrm{g}^{-1} \mathrm{FW}\right)$ and alkaline phosphatase activity $\left(0.119 \pm 0.008 \mathrm{IU} \mathrm{g}^{-1} \mathrm{FW}\right)$. The percentage mycorrhizal root colonization with the A. laevis $+P$. fluorescens $(86.86 \pm 2.17 \%)$ combination and chlorophyll content with the $G$. mosseae + A. laevis + P. fluorescens $(0.474 \pm 0.009 \mathrm{mg}$ $\mathrm{g}^{-1} \mathrm{FW}$ ) combination recorded the highest values at the low concentration (half recommended superphosphate dose) as compared with non-mycorrhizal plants (control). The high superphosphate dose clearly reduced or decreased all the growth parameters. Therefore, vigorous growth and maximum flax yield can be achieved by inoculating plants with AM fungi and $P$. fluorescens with the recommended dose or less than the recommended dose of superphosphate.
\end{abstract}

Key words: Linum usitatissimum, AM fungi, Pseudomonas fluorescens, $\mathrm{P}$ uptake, $\mathrm{P}$ activity.

$\mathrm{F}$ laxseed (Linum usitatissimum L.) is a member of the genus Linum, it belongs to the Linaceae family and originated in Europe and Southern Asia. Flax is now a prominent dual-purpose crop which is a source of oil and fibers. Raw linseed oil is used in pharmaceuticals as an emollient, demulcent, expectorant, and diuretic. Linseed oil acts as a nutritional supplement and a component in many wood finishing products. The oil is also employed to prepare lubricants, greases, and polishes. It has been primarily used to manufacture paints and varnishes (Charlton and Ehrensing, 2001) and make linoleum floor tiles (Metrycki, 2004).

In Ayurveda, India's traditional, natural system of medicine, flax is used internally in cases of chronic constipation, functional disorders of the colon resulting from the misuse of laxatives, and irritable colon; it is used as a demulcent preparation in gastritis and enteritis, and as an emollient in poultices for boils, carbuncles, and other skin afflictions. As a result of its valuable medicinal properties, flax is also important industrially.

${ }^{1}$ Kurukshetra University, Department of Botany, Kurukshetra, Haryana, India. "Corresponding author (aggarwal_vibha@rediffmail.com). Received: 12 September 2011.

Accepted: 23 May 2012.
The fine grades of flax are woven into fabrics, such as cambrics, damasks, sheetings, laces for apparel, household furnishings, and linen thread. Although its value is significant, its productivity and yield are quite low. The reasons for low flax yield are poor soil fertility, inadequate use of fertilizers, and traditional crop management practices. It is therefore necessary to increase flax productivity, which can be achieved by improving agricultural and forestry practices. Arbuscular mycorrhizal fungi and Pseudomonas fluorescens improve linseed growth and yield. It has been reported for linseed that a single inoculation of AM fungi Glomus mosseae and Acaulospora laevis resulted in various increased morphological and physiological parameters, such as mycorrhizal spore number, mycorrhizal root colonization, chlorophyll content, and acidic and alkaline phosphatase activity as compared with $P$. fluorescens when used alone (Neetu et al., 2011).

Since fiber-yielding plants are very important, a lot of work has been done to enhance their growth by using different bioinoculants such as AM fungi and various fertilizers. Arbuscular mycorrhizal fungi increases plant $\mathrm{P}$ uptake by reducing the distance ions must diffuse (Sanders and Tinker, 1973). Arbuscular mycorrhizal-dependent plants very often absorb and store more $\mathrm{P}$ than is required 
to satisfy growth (Shibata and Yano, 2003; Pasqualini et al., 2007). Applying fertilizers is also gaining attention nowadays because of their importance for vigorous growth and higher yields of different plant species; however, their effect on soil pollution and non-target (beneficial) organisms, especially AM fungi, was seldom understood. A significant increment in seed yield, oil content, and oil yield was observed when L. usitatissimum was inoculated with NPK fertilizers (Berti et al., 2009). Ali et al. (2002) reported that seed weight, seed yield, and oil content of L. usitatissimum were significantly influenced by applying P. Similarly, Saleem et al. (2010) observed the effect of different $P$ levels on earliness and yield of cotton cultivars. Moreover, applying mineral fertilizers can also influence or enhance phosphatase activity. A large proportion of soil $\mathrm{P}$ is in the organically bound state, and its mineralization is agriculturallyimportant. Phosphatase enzymes are responsible for soil organic P mineralization and the release of inorganic $P$ required by the plants.

Soil acid phosphatase activity comes from many sources, including plant root, mycorrhizal fungi, and bacteria, while alkaline phosphatases are produced by soil microorganisms and soil fauna, but higher plants are devoid of alkaline phosphatase (Eichler et al., 2004). Supatra and Mukherji (2004) reported that enhanced phosphatase activities increase $\mathrm{P}$ availability in P-deficient seasons. Phosphatases are believed to be important for $\mathrm{P}$ scavenging and remobilization in plants (Sharma et al., 2004). Bhatt et al. (2011) recently showed the positive interaction between alkaline phosphatase activity and the specific soil characteristics of different plants in Gujarat, India.

The objective of this study was to find a fertilizer treatment adequate for both symbiosis partners, improve linseed growth, and support the occurrence and development of AM fungi during the growth period. This study aimed to observe the effect of AM fungi alone or combined with Pseudomonas fluorescens (PSB) at different superphosphate levels on linseed growth and yield.

\section{MATERIALS AND METHODS}

\section{Soil sample collection}

To isolate the dominant AM fungi, composite rhizospheric soil samples of L. usitatissimum were collected. This was done by digging out a small amount of soil close to the plant roots up to 15 to $30 \mathrm{~cm}$ depth, which were kept in sterilized polythene bags at $10^{\circ} \mathrm{C}$ for further processing.

\section{Isolation of dominant AM spores from soil samples}

Isolation of dominant AM spores G. mosseae (T.H. Nicolson \& Gerd.) Gerd. \& Trappe and A. laevis (Gerd. \& Trappe) was done by Gerdemann and Nicolson's (1963) Wet Sieving and Decanting Technique. With this technique, $50 \mathrm{~g}$ of soil were soaked in $500 \mathrm{~mL}$ water for
$24 \mathrm{~h}$. The supernatant was then passed through a gradient of sieves with pore sizes ranging from $150 \mu \mathrm{m}$ to 45 $\mu \mathrm{m}$ arranged one above the other in an ascending order. Each sieve was then washed in water which was filtered through Whatman $\mathrm{N}^{\circ} 1$ filter paper. This filter paper was then observed under a stereo binocular microscope to observe various kinds of spores; it was mounted on polyvinyl lactic acid (PVLA) for further studies.

\section{Quantification of AM spores and identification of AM fungi}

This was done by the Grid Line Intersect Method (Gaur and Adholeya, 1994). Spores were counted under a stereo binocular microscope with a counter.

The AM spores (G. mosseae and A. laevis) were identified with the identification manuals by Walker (1983), Schenck and Perez (1990), Morton and Benny (1990), and Mukerji (1996).

\section{Mycorrhizal root colonization}

Roots were washed from the soil, blotted dry to determine fresh and dry root weight, $\mathrm{P}$ content, and mycorrhizal root colonization. Mycorrhizal root colonization was done by the Rapid Clearing and Staining Method (Phillips and Hayman, 1970). The percentage of AM root colonization was determined as:

$$
\begin{aligned}
& \text { Percentage root } \\
& \text { colonization }
\end{aligned}=\frac{\begin{array}{c}
\text { Number of root } \\
\text { segments colonized }
\end{array}}{\begin{array}{c}
\text { Number of root } \\
\text { segments } \text { studied }
\end{array}} \times 100
$$

Mass production of AM spores and mass culture of Pseudomonas fluorescens

Dominant AM spores of Glomus mosseae and Acaulospora laevis were isolated from rhizospheric soil of L. usitatissimum and mass-multiplied with wheat as the host plant because of its better root system (Mangla et al., 2010).

Pseudomonas fluorescens (MTCC $\mathrm{N}^{\circ}$ B103) was procured from IMTECH (Institute of Microbial Technology, Chandigarh, India) and multiplied in nutrient broth medium (1.25 g peptone, $0.75 \mathrm{~g}$ beef extract, $1.25 \mathrm{~g}$ $\mathrm{NaCl}, 250 \mathrm{~mL}$ distilled water) for $24 \mathrm{~h}$ for suitable bacteria growth.

\section{Different superphosphate concentrations}

Granules of superphosphate, generally used as fertilizer by farmers in Haryana and its adjoining areas, were ground to a fine powder with a pestle and mortar. Then, superphosphate was applied in different concentrations: low, medium, and high. Medium is the recommended concentration (1500 mg $3 \mathrm{~kg}^{-1}$ soil), low is half the recommended dose (750 mg $3 \mathrm{~kg}^{-1}$ soil), and high is double the recommended dose (3000 mg $3 \mathrm{~kg}^{-1}$ soil).

\section{Pot mixture preparation}

The soil we used in the present investigation came 
from the Botanical Garden of Kurukshetra University, Kurukshetra which had not been previously used for linseed propagation and had $\mathrm{pH} 8.08,64.2 \%$ sand, $21.81 \%$ silt, $3.90 \%$ clay, $9.5 \mathrm{~kg} \mathrm{P} \mathrm{ha}^{-1}, 0.042 \%$ total $\mathrm{N}$ content, $0.43 \%$ organic $\mathrm{C}$, and $0.017 \%$ available $\mathrm{P}$. The soil was sterilized for two consecutive days at $15 \mathrm{lb}$ pressure. There were no AM mycelia and spores in the soil. The sterilized soil was put into the earthen pots $(25 \mathrm{~cm} \times 25 \mathrm{~cm})$. Approximately 486 AM spores and $P$. fluorescens with $1 \times 10^{-9} \mathrm{cfu}$ were added in accordance with the different pot treatments. Surface-sterilized seeds of L. usitatissimum were grown in earthen pots under polyhouse conditions. Ten percent inocula of each AM fungi (300 g soil with AM spores and colonized roots for single inoculation and double inoculation of G. mosseae and A. laevis, $150 \mathrm{~g}$ soil with spores and colonized roots of both Glomus and Acaulospora for triple inoculation) were added to each pot alone and combined with $P$. fluorescens at different superphosphate concentrations. After 120 d (seed formation stage) of inoculation, the consortium effect of these bioinoculants and different superphosphate levels were recorded for different growth parameters of L. usitatissimum. The different treatments of the present investigation were: a) Control; b) G. mosseae; c) A. laevis; d) G. mosseae + P. fluorescens; e) A. laevis + P. fluorescens; and f) G. mosseae + A. laevis + P.fluorescens. Each treatment was replicated five times.

\section{Growth parameter analysis Fresh/dry root/shoot weight, and chlorophyll content}

To assess growth, fresh/dry root weight, and fresh/dry shoot weight roots and shoots were harvested after $120 \mathrm{~d}$, weighed for fresh weight and then oven-dried at $70{ }^{\circ} \mathrm{C}$ to measure dry weight.

The amounts of chlorophyll a, chlorophyll $b$, and total chlorophyll were estimated by Arnon's (1949) method.

\section{Phosphorus estimation and phosphatase activity}

Phosphorus was estimated by the vanadomolybdophosphoric yellow color method (Jackson, 1973).

Phosphatase activity was assayed with p-nitrophenyl phosphate (PNPP) as substrate, which is hydrolyzed by the enzyme to p-nitrophenol (Tabatabai and Bremner, 1969).

\section{Statistical analysis}

All results were analyzed with ANOVA followed by the post hoc test with the SPSS 11.5 version computer software. Means were ranked for comparison at a level of significance of $\mathrm{P} \leq 0.005$ by Duncan's Multiple Range Test.

\section{RESULTS AND DISCUSSION}

\section{Height change}

The present investigation found that superphosphate inoculation with significant bioinoculants such as AM fungi and P. fluorescens increased plant height as compared with the control (Table 1). After $120 \mathrm{~d}$ of inoculation, the most effective results were observed at the medium concentration where the recommended $\mathrm{P}$ dose with various bioinoculants was applied to the plant. The

Table 1. Consortium effect of arbuscular mycorrhizal (AM) fungi, Pseudomonas fluorescens, and superphosphate on growth parameters of Linum usitatissimum after $120 \mathrm{~d}$ of inoculation.

\begin{tabular}{|c|c|c|c|c|c|c|c|c|c|}
\hline Concentration & Treatments & $\begin{array}{l}\text { Plant } \\
\text { height }\end{array}$ & $\begin{array}{c}\text { Fresh shoot } \\
\text { weight }\end{array}$ & $\begin{array}{c}\text { Dry shoot } \\
\text { weight }\end{array}$ & $\begin{array}{l}\text { Fresh root } \\
\text { weight }\end{array}$ & $\begin{array}{c}\text { Dry root } \\
\text { weight }\end{array}$ & $\begin{array}{l}\text { Root } \\
\text { length }\end{array}$ & $\begin{array}{l}\text { AM spore } \\
10 \mathrm{~g}^{-1} \text { soil }\end{array}$ & $\begin{array}{c}\text { AM root } \\
\text { colonization }\end{array}$ \\
\hline $\begin{array}{l}\text { Low } \\
\text { concentration }\end{array}$ & $\begin{array}{l}\text { Control } \\
\text { G. mosseae } \\
\text { A. laevis } \\
\mathrm{G}+\mathrm{P} \\
\mathrm{A}+\mathrm{P} \\
\mathrm{G}+\mathrm{A}+\mathrm{P}\end{array}$ & $\begin{array}{c}\mathrm{cm} \\
44.8 \pm 2.1 \mathrm{ef} \\
68.7 \pm 3.3 \mathrm{~cd} \\
72.7 \pm 1.5 \mathrm{bc} \\
58.0 \pm 2.1 \mathrm{de} \\
55.5 \pm 2.9 \mathrm{de} \\
69.6 \pm 3.2 \mathrm{~cd}\end{array}$ & $\begin{array}{l}1.24 \pm 0.143 \mathrm{ef} \\
2.34 \pm 0.227 \mathrm{c} \\
2.26 \pm 0.156 \mathrm{c} \\
2.41 \pm 0.174 \mathrm{c} \\
1.87 \pm 0.094 \mathrm{~cd} \\
2.89 \pm 0.055 b\end{array}$ & $\begin{array}{l}0.18 \pm 0.012 \mathrm{f} \\
0.34 \pm 0.017 \mathrm{c} \\
0.31 \pm 0.016 \mathrm{~cd} \\
0.39 \pm 0.021 \mathrm{bc} \\
0.27 \pm 0.012 \mathrm{~d} \\
0.44 \pm 0.018 \mathrm{~b}\end{array}$ & $\begin{array}{l}\mathrm{g} \\
0.04 \pm 0.004 \mathrm{f} \\
0.09 \pm 0.009 \mathrm{~d} \\
0.11 \pm 0.013 \mathrm{~cd} \\
0.19 \pm 0.019 \mathrm{ab} \\
0.18 \pm 0.021 \mathrm{ab} \\
0.15 \pm 0.006 \mathrm{bc}\end{array}$ & $\begin{array}{l}0.007 \pm 0.001 \mathrm{f} \\
0.016 \pm 0.002 \mathrm{~d} \\
0.018 \pm 0.002 \mathrm{~cd} \\
0.034 \pm 0.002 \mathrm{ab} \\
0.033 \pm 0.001 \mathrm{ab} \\
0.027 \pm 0.002 \mathrm{bc}\end{array}$ & $\begin{array}{c}\mathrm{cm} \\
6.06 \pm 0.60 \mathrm{f} \\
8.79 \pm 0.73 \mathrm{~d} \\
14.92 \pm 0.74 \mathrm{~b} \\
12.61 \pm 0.73 \mathrm{bc} \\
9.69 \pm 0.48 \mathrm{~cd} \\
11.91 \pm 0.73 \mathrm{c}\end{array}$ & $\begin{array}{l}16.20 \pm 4.32 \mathrm{de} \\
19.40 \pm 5.22 \mathrm{~d} \\
30.00 \pm 7.17 \mathrm{c} \\
28.60 \pm 5.59 \mathrm{~cd} \\
56.40 \pm 7.12 \mathrm{~b} \\
68.00 \pm 5.91 \mathrm{ab}\end{array}$ & $\begin{array}{c}\% \\
31.40 \pm 1.84 \mathrm{e} \\
64.09 \pm 1.99 \mathrm{bc} \\
41.26 \pm 2.02 \mathrm{~d} \\
50.91 \pm 2.12 \mathrm{~cd} \\
86.86 \pm 2.17 \mathrm{a} \\
85.78 \pm 2.27 \mathrm{ab}\end{array}$ \\
\hline $\begin{array}{l}\text { Medium } \\
\text { concentration }\end{array}$ & $\begin{array}{l}\text { Control } \\
\text { G. mosseae } \\
\text { A. laevis } \\
\mathrm{G}+\mathrm{P} \\
\mathrm{A}+\mathrm{P} \\
\mathrm{G}+\mathrm{A}+\mathrm{P}\end{array}$ & $\begin{array}{l}47.8 \pm 2.4 \mathrm{de} \\
64.2 \pm 2.6 \mathrm{~d} \\
71.4 \pm 1.9 \mathrm{bc} \\
78.7 \pm 1.8 \mathrm{a} \\
76.6 \pm 2.2 \mathrm{ab} \\
75.2 \pm 1.7 \mathrm{~b}\end{array}$ & $\begin{array}{l}1.33 \pm 0.082 \mathrm{ef} \\
2.65 \pm 0.188 \mathrm{bc} \\
2.76 \pm 0.190 \mathrm{bc} \\
3.45 \pm 0.294 \mathrm{a} \\
3.28 \pm 0.128 \mathrm{ab} \\
3.22 \pm 0.105 \mathrm{ab}\end{array}$ & $\begin{array}{l}0.19 \pm 0.011 \mathrm{ef} \\
0.40 \pm 0.018 \mathrm{bc} \\
0.43 \pm 0.017 \mathrm{~b} \\
0.57 \pm 0.007 \mathrm{a} \\
0.54 \pm 0.009 \mathrm{ab} \\
0.52 \pm 0.015 \mathrm{ab}\end{array}$ & $\begin{array}{l}0.05 \pm 0.006 \mathrm{e} \\
0.07 \pm 0.013 \mathrm{de} \\
0.20 \pm 0.019 \mathrm{ab} \\
0.22 \pm 0.023 \mathrm{a} \\
0.17 \pm 0.011 \mathrm{~b} \\
0.16 \pm 0.010 \mathrm{bc}\end{array}$ & $\begin{array}{l}0.009 \pm 0.001 \mathrm{ef} \\
0.013 \pm 0.001 \mathrm{e} \\
0.035 \pm 0.004 \mathrm{ab} \\
0.036 \pm 0.004 \mathrm{a} \\
0.030 \pm 0.002 \mathrm{~b} \\
0.029 \pm 0.001 \mathrm{~b}\end{array}$ & $\begin{array}{c}7.10 \pm 0.52 \mathrm{de} \\
10.40 \pm 0.59 \mathrm{~cd} \\
16.19 \pm 0.64 \mathrm{ab} \\
15.82 \pm 0.46 \mathrm{ab} \\
17.67 \pm 0.48 \mathrm{a} \\
16.20 \pm 0.81 \mathrm{ab}\end{array}$ & $\begin{array}{l}18.00 \pm 6.20 \mathrm{~d} \\
22.80 \pm 6.09 \mathrm{~cd} \\
52.20 \pm 7.52 \mathrm{~b} \\
94.40 \pm 9.86 \mathrm{a} \\
74.80 \pm 10.2 \mathrm{ab} \\
72.80 \pm 8.10 \mathrm{ab}\end{array}$ & $\begin{array}{l}21.93 \pm 2.32 \mathrm{ef} \\
53.16 \pm 2.08 \mathrm{~cd} \\
68.23 \pm 2.70 \mathrm{bc} \\
77.85 \pm 2.20 \mathrm{~b} \\
55.34 \pm 2.95 \mathrm{c} \\
71.91 \pm 1.98 \mathrm{~b}\end{array}$ \\
\hline $\begin{array}{l}\text { High } \\
\text { concentration }\end{array}$ & $\begin{array}{l}\text { Control } \\
\text { G. mosseae } \\
\text { A. laevis } \\
\mathrm{G}+\mathrm{P} \\
\mathrm{A}+\mathrm{P} \\
\mathrm{G}+\mathrm{A}+\mathrm{P} \\
\mathrm{LSD}(\mathrm{P} \leq 0.05) \\
\text { ANOVA }\left(\mathrm{F}_{15,32}\right)\end{array}$ & $\begin{array}{c}43.1 \pm 1.1 \mathrm{f} \\
63.5 \pm 2.9 \mathrm{~d} \\
53.9 \pm 3.7 \mathrm{de} \\
70.6 \pm 2.3 \mathrm{c} \\
68.3 \pm 2.9 \mathrm{~cd} \\
65.6 \pm 3.2 \mathrm{~d} \\
6.46 \\
90.762\end{array}$ & $\begin{array}{c}0.90 \pm 0.004 \mathrm{f} \\
2.09 \pm 0.107 \mathrm{c} \\
1.68 \pm 0.138 \mathrm{~cd} \\
3.10 \pm 0.097 \mathrm{ab} \\
1.75 \pm 0.137 \mathrm{~cd} \\
2.37 \pm 0.121 \mathrm{c} \\
0.3783 \\
122.707\end{array}$ & $\begin{array}{c}0.17 \pm 0.004 \mathrm{ef} \\
0.29 \pm 0.017 \mathrm{~cd} \\
0.20 \pm 0.012 \mathrm{de} \\
0.46 \pm 0.014 \mathrm{~b} \\
0.24 \pm 0.019 \mathrm{de} \\
0.37 \pm 0.018 \mathrm{c} \\
0.0382 \\
361.828\end{array}$ & $\begin{array}{c}0.045 \pm 0.007 \mathrm{ef} \\
0.06 \pm 0.005 \mathrm{de} \\
0.08 \pm 0.005 \mathrm{~d} \\
0.12 \pm 0.009 \mathrm{~cd} \\
0.13 \pm 0.009 \mathrm{c} \\
0.14 \pm 0.009 \mathrm{c} \\
0.0317 \\
104.600\end{array}$ & $\begin{array}{c}0.008 \pm 0.001 \mathrm{ef} \\
0.011 \pm 0.002 \mathrm{e} \\
0.015 \pm 0.001 \mathrm{de} \\
0.021 \pm 0.001 \mathrm{c} \\
0.022 \pm 0.001 \mathrm{c} \\
0.025 \pm 0.001 \mathrm{bc} \\
0.0052 \\
112.290\end{array}$ & $\begin{array}{c}6.79 \pm 0.51 \mathrm{e} \\
7.30 \pm 0.83 \mathrm{de} \\
8.34 \pm 0.50 \mathrm{~d} \\
11.11 \pm 0.72 \mathrm{c} \\
13.89 \pm 0.83 \mathrm{~b} \\
13.01 \pm 0.33 \mathrm{~b} \\
1.6384 \\
162.600\end{array}$ & $\begin{array}{c}9.80 \pm 3.56 \mathrm{e} \\
25.20 \pm 5.26 \mathrm{~cd} \\
37.60 \pm 8.35 \mathrm{c} \\
24.80 \pm 5.11 \mathrm{~cd} \\
33.80 \pm 6.22 \mathrm{c} \\
44.00 \pm 7.17 \mathrm{bc} \\
17.244 \\
62.052\end{array}$ & $\begin{array}{c}14.22 \pm 2.87 \mathrm{f} \\
51.12 \pm 1.84 \mathrm{~cd} \\
35.47 \pm 1.58 \mathrm{de} \\
42.60 \pm 2.00 \mathrm{~d} \\
36.98 \pm 2.38 \mathrm{de} \\
43.53 \pm 1.68 \mathrm{~d} \\
5.553 \\
447.271\end{array}$ \\
\hline F values & $\begin{array}{l}\text { Fertilizer }(f) \\
\text { Parameter }(p) \\
f \times p\end{array}$ & $\begin{array}{r}95.330 \\
173.872 \\
46.463\end{array}$ & $\begin{array}{r}99.581 \\
262.364 \\
36.216\end{array}$ & $\begin{array}{c}593.111 \\
657.513 \\
99.437\end{array}$ & $\begin{array}{c}47.685 \\
592.085 \\
17.962\end{array}$ & $\begin{array}{c}112.190 \\
137.970 \\
7.722\end{array}$ & $\begin{array}{r}353.782 \\
423.679 \\
45.309\end{array}$ & $\begin{array}{r}79.960 \\
130.124 \\
28.853\end{array}$ & $\begin{array}{r}1467.207 \\
1519.423 \\
135.344\end{array}$ \\
\hline
\end{tabular}

G: Glomusmosseae; A: Acaulospora laevis; P: Pseudomonas fluorescens

\pm Standard deviation, the mean difference is significant at a 0.5 level.

Mean value followed by different letters in a column do not differ significantly according to Duncan's Multiple Range Test $(\mathrm{P} \leq 0.05)$. 
low superphosphate concentration (half recommended dose) with AM fungi (G. mosseae and A. laevis) and $P$. fluorescens also showed effective results in increased plant height. It is evident from Table 1 that maximum plant height was in the G. mosseae $+P$. fluorescens dual combination $(78.74 \pm 1.8 \mathrm{~cm})$, followed by A. laevis $+P$. fluorescens $(76.58 \pm 2.2 \mathrm{~cm})$, and then the G. mosseae $+A$ laevis $+P$. fluorescens $(75.18 \pm 1.7 \mathrm{~cm})$ triple combination for the medium concentration. Such positive improvement in plant height could be due to increased plant metabolic processes resulting in greater plant meristematic activities and apical growth. According to the results of the growth attributes shown in Table 1, P. fluorescens was found to be a common effective bioinoculant increasing plant height. The reason for the increase in plant growth could be due to the suppression of plant pathogenic microbes, production of growth-stimulating plant hormones, and the promoting effect of $P$. fluorescens on plant disease resistance. Our results are similar to those by Sridevi and Ramakrishnan (2010), who observed a significant increase in the height of cotton plants during the growth period when plants were inoculated with NPK fertilizers and AM fungi. Likewise, Prasad and Bilgrami (2002) observed that inoculating Saccharum officinarum with Glomus fasciculatum at different phosphate levels trigger plant height.

\section{Fresh/dry shoot/root weight}

The biomass of all inoculated L. usitatissimum plants increased significantly in terms of fresh/dry shoot/ root weight after $120 \mathrm{~d}$ of inoculation (Table 1). The maximum increase in shoot biomass was recorded in the G. mosseae $+P$. fluorescens $(3.45 \pm 0.294,0.57 \pm 0.007$ g) combination, followed by $A$. laevis $+P$. fluorescens $(3.28 \pm 0.128,0.54 \pm 0.009 \mathrm{~g})$, and then the $G$. mosseae + A. laevis + P. fluorescens $(3.22 \pm 0.105,0.52 \pm 0.015$ g) triple combination at the medium concentration where the recommended $\mathrm{P}$ dose with various bioinoculants was applied to the plant. Similar results were obtained for root biomass. Root biomass (fresh and dry) increased significantly over the control regardless of the treatments (Table 1). After $120 \mathrm{~d}$, the increase in root biomass was observed at high and medium concentrations with the $G$. mosseae $+P$. fluorescens $(0.223 \pm 0.023,0.036 \pm 0.004$ g) combination and followed by the single inoculation with A. laevis $(0.197 \pm 0.019,0.035 \pm 0.004 \mathrm{~g})$. This confirms the earlier findings by Davis et al. (1979), who observed the increase in dry root weight of cotton when soil is amended with AM fungi (G. fasciculatus) and $300 \mu \mathrm{g}$ P. Earlier studies have also shown that cotton plant biomass increased significantly when the plant was inoculated with NPK fertilizer and AM fungi (Sridevi and Ramakrishnan, 2010). The second most effective results in both shoot and root biomass increase were observed at the low concentration in which half the recommended dose was applied to the plants. The high superphosphate concentration clearly reduced shoot and root linseed biomass (Table 1).

\section{Root length}

Inoculating L. usitatissimum with various bioinoculants and superphosphate significantly increased root length after $120 \mathrm{~d}$ of inoculation (Table 1). In the present study, the medium concentration (recommended dose) was found to be more effective for increasing root length. Plants inoculated with the medium superphosphate concentration along with AM fungi and P. fluorescens showed the maximum root length increase in the A. laevis $+P$. fluorescens $(17.67 \pm 0.48 \mathrm{~cm})$ combination, followed by the $G$. mosseae + A. laevis $+P$. fluorescens (16.20 \pm $0.81 \mathrm{~cm}$ ) triple combination, and then with the A. laevis $(16.19 \pm 0.64 \mathrm{~cm})$ single inoculation. Our results agree with findings by Thingstrup et al. (1998), who observed a significant increase in specific root length and root length density of L. usitatissimum when the plants were inoculated with different doses of $\mathrm{P}$ fertilizer. According to the result attributes, it can be concluded that AM fungi with $P$. fluorescens also help to increase root length at the recommended $\mathrm{P}$ level (Table 1). The low $\mathrm{P}$ concentration (half recommended dose) also showed effective results (Table 1). Torrisi et al. (1999) observed that root length increased in cotton plants when soil was inoculated with an isolate of G. mosseae. As a result of P. fluorescens and AMF treatment, root elongation was observed, which ultimately absorbed more nutrients, especially from the $\mathrm{P}$ depletion zone and resulted in the best plant growth as compared with the uninoculated plants.

\section{Root colonization and AM spore number}

The percentage of mycorrhizal root colonization and AM spore number also increased in all the treated plants as compared with the control (Table 1). After $120 \mathrm{~d}$ of inoculation it was observed that the maximum AM spore number was in the $G$. mosseae $+P$. fluorescens $(94.4 \pm$ 9.86) combination, followed by $A$. laevis $+P$. fluorescens $(74.8 \pm 10.25)$, and then in the G. mosseae + A. laevis $+P$. fluorescens $(72.8 \pm 8.10)$ triple combination at the medium concentration (i.e., recommended $\mathrm{P}$ dose). The highest percentage of mycorrhizal root colonization was in the A. laevis $+P$. fluorescens $(86.86 \pm 2.17 \%)$ treatment and followed by $G$. mosseae + A. laevis $+P$. fluorescens $(85.78 \pm 2.27 \%)$ at the low concentration where half the recommended dose was applied to the plant. It can be concluded that the high $\mathrm{P}$ application (double recommended dose) effectively suppressed the percentage of root colonization and AM spore number in linseed plants (Table 1). These results are similar to those found by Davis et al. (1979) in the cotton plant and who observed the effective results in the percentage of mycorrhizal root colonization at $20 \mu \mathrm{g}$ P level with $G$. fasciculatus as compared with $300 \mu \mathrm{g}$ P level with the same AM fungi. Pseudomonas species are also effective 
root colonizers since they produce secondary metabolites (O'Sullivan and O'Gara, 1992) that enhance AMF growth and therefore, mycorrhizal spore number and colonization. It was observed that plant inoculation with AM fungi and $P$. fluorescens alone or combined with different superphosphate levels showed a significant increase in mycorrhizal root colonization and AM spore number. The reason could be that the phosphate solubilizing bacteria $P$. fluorescens behaved as mycorrhizal helper bacteria promoting a higher colonization rate and AM spore number. They also help in mineral phosphate solubilization and contribute to biogeochemical P cycling, thus promoting a sustainable nutrient supply to the crop plants for higher yield.

\section{Chlorophyll content}

Chlorophyll content increased in all treated plants as compared with the control. Applying half the recommended superphosphate fertilizer dose with AM fungi and $P$. fluorescens inoculation clearly improved chlorophyll content in L. usitatissimum (Table 2). The highest increase in total chlorophyll content was observed in the G. mosseae + A. laevis + P. fluorescens $\left(0.474 \pm 0.009 \mathrm{mg} \mathrm{g}^{-1} \mathrm{FW}\right)$ triple inoculation at the low concentration (half recommended dose). The second most effective results were observed in the $G$. mosseae + A. laevis + P. fluorescens $\left(0.440 \pm 0.011 \mathrm{mg} \mathrm{g}^{-1} \mathrm{FW}\right)$ tripartite inoculation followed by the $G$. mosseae $+P$. fluorescens $\left(0.407 \pm 0.007 \mathrm{mg} \mathrm{g}^{-1} \mathrm{FW}\right)$ dual inoculation at the medium concentration. The high $\mathrm{P}$ concentration (double recommended dose) decreased total chlorophyll content (Table 2). The results are in accordance with the study by Prasad and Bilgrami (2002), who observed that inoculating Saccharum officinarum with Glomus fasciculatum at a low phosphate dose triggers chlorophyll content as compared with the control. Inoculation with AM fungi also shows effective results for increasing chlorophyll content. An increase in chlorophyll content in mycorrhizal-treated plants indicates an increase in the photosynthesis rate, which can be due to a higher nutrient absorption. Inoculation of Helianthus annuus with $\operatorname{AMF}$ (G. mosseae, G. deserticola, G. aggregatum, and Gigaspora margarita) showed a significant increase in chlorophyll content (Nagarajan and Mahadevan, 2002).

\section{Phosphorus content}

It is clear that inoculating soil with AM fungi, $P$. fluorescens, and different levels of superphosphate clearly improved $\mathrm{P}$ content in L. usitatissimum as compared with the control (Table 2). After $120 \mathrm{~d}$ of inoculation, the increase in shoot and root $\mathrm{P}$ content was the highest in plants treated with $G$. mosseae $+P$. fluorescens $(1.14 \pm$ $0.11 \%)$ for shoot and $(1.29 \pm 0.11 \%)$ for root, followed by G. mosseae+ A. laevis + P. fluorescens $(0.88 \pm 0.098 \%)$ for shoot and $(0.95 \pm 0.082 \%)$ for root at the medium concentration. Triple inoculation of $G$. mosseae $+A$. laevis $+P$. fluorescens $(0.779 \pm 0.139 \%)$ for shoot and $(0.903 \pm 0.082 \%)$ for root at the low P concentration (half recommended dose) also showed effective results for increasing $\mathrm{P}$ content. These results are similar to those by Cavagnaro et al. (2005), who observed that shoot and root P content of L. usitatissimum increased significantly when

Table 2. Consortium effect of arbuscular mycorrhizal (AM) fungi, Pseudomonas fluorescens, and superphosphate on growth parameters of Linum usitatissimum after $120 \mathrm{~d}$ of inoculation.

\begin{tabular}{|c|c|c|c|c|c|c|c|c|}
\hline Concentration & Treatments & Chlorophyll a & Chlorophyll b & $\begin{array}{c}\text { Total } \\
\text { chlorophyll }\end{array}$ & Shoot P & Root P & $\begin{array}{c}\text { Acidic } \\
\text { phosphatase }\end{array}$ & $\begin{array}{c}\text { Alkaline } \\
\text { phosphatase }\end{array}$ \\
\hline \multirow{7}{*}{$\begin{array}{l}\text { Low } \\
\text { concentration }\end{array}$} & & \multicolumn{3}{|c|}{$\mathrm{mg} \mathrm{g}^{-1} \mathrm{FW}$} & \multicolumn{2}{|c|}{$\%$} & \multicolumn{2}{|c|}{$\mathrm{IUg}^{-1} \mathrm{FW}$} \\
\hline & Control & $0.130 \pm 0.004 \mathrm{ef}$ & $0.033 \pm 0.008 \mathrm{ef}$ & $0.164 \pm 0.011 \mathrm{ef}$ & $0.31 \pm 0.08 \mathrm{ef}$ & $0.33 \pm 0.07 \mathrm{ef}$ & $0.11 \pm 0.01 \mathrm{de}$ & $0.029 \pm 0.008 \mathrm{ef}$ \\
\hline & G. mosseae & $0.188 \pm 0.005 \mathrm{~cd}$ & $0.055 \pm 0.007 \mathrm{~cd}$ & $0.244 \pm 0.011 \mathrm{~d}$ & $0.43 \pm 0.08 \mathrm{~cd}$ & $0.53 \pm 0.07 \mathrm{~d}$ & $0.31 \pm 0.01 \mathrm{c}$ & $0.057 \pm 0.010 \mathrm{~d}$ \\
\hline & A. laevis & $0.175 \pm 0.005 \mathrm{~cd}$ & $0.047 \pm 0.006 \mathrm{~cd}$ & $0.222 \pm 0.007 \mathrm{~d}$ & $0.38 \pm 0.11 \mathrm{~d}$ & $0.43 \pm 0.07 \mathrm{de}$ & $0.30 \pm 0.01 \mathrm{c}$ & $0.053 \pm 0.006 \mathrm{~d}$ \\
\hline & $\mathrm{G}+\mathrm{P}$ & $0.249 \pm 0.004 b c$ & $0.092 \pm 0.006 \mathrm{bc}$ & $0.341 \pm 0.007 \mathrm{~b}$ & $0.73 \pm 0.06 b$ & $0.81 \pm 0.10 b$ & $0.42 \pm 0.02 \mathrm{ab}$ & $0.098 \pm 0.009 \mathrm{ab}$ \\
\hline & $\mathrm{A}+\mathrm{P}$ & $0.227 \pm 0.006 \mathrm{c}$ & $0.075 \pm 0.008 \mathrm{c}$ & $0.302 \pm 0.003 c$ & $0.72 \pm 0.11 b$ & $0.73 \pm 0.08 b c$ & $0.38 \pm 0.02 b$ & $0.088 \pm 0.010 \mathrm{~b}$ \\
\hline & $\mathrm{G}+\mathrm{A}+\mathrm{P}$ & $0.329 \pm 0.005 \mathrm{a}$ & $0.144 \pm 0.006 \mathrm{a}$ & $0.474 \pm 0.009 \mathrm{a}$ & $0.78 \pm 0.13 b$ & $0.90 \pm 0.08 \mathrm{ab}$ & $0.43 \pm 0.01 \mathrm{ab}$ & $0.101 \pm 0.010 \mathrm{ab}$ \\
\hline \multirow{6}{*}{$\begin{array}{l}\text { Medium } \\
\text { concentration }\end{array}$} & Control & $0.136 \pm 0.005 \mathrm{e}$ & $0.038 \pm 0.007 \mathrm{f}$ & $0.174 \pm 0.006 \mathrm{e}$ & $0.30 \pm 0.11 \mathrm{ef}$ & $0.38 \pm 0.10 \mathrm{e}$ & $0.09 \pm 0.01 \mathrm{e}$ & $0.022 \pm 0.007 \mathrm{ef}$ \\
\hline & G.mosseae & $0.238 \pm 0.007 \mathrm{bc}$ & $0.086 \pm 0.011 b c$ & $0.325 \pm 0.007 b c$ & $0.58 \pm 0.09 \mathrm{c}$ & $0.67 \pm 0.09 c$ & $0.37 \pm 0.01 b$ & $0.082 \pm 0.010 \mathrm{bc}$ \\
\hline & A. laevis & $0.206 \pm 0.004 \mathrm{~cd}$ & $0.069 \pm 0.010 \mathrm{~cd}$ & $0.275 \pm 0.013 \mathrm{~cd}$ & $0.52 \pm 0.06 \mathrm{c}$ & $0.66 \pm 0.11 \mathrm{c}$ & $0.35 \pm 0.01 b c$ & $0.068 \pm 0.014 \mathrm{~cd}$ \\
\hline & $G+P$ & $0.298 \pm 0.007 \mathrm{ab}$ & $0.108 \pm 0.007 \mathrm{ab}$ & $0.407 \pm 0.007 \mathrm{ab}$ & $1.14 \pm 0.11 \mathrm{a}$ & $1.29 \pm 0.11 \mathrm{a}$ & $0.44 \pm 0.01 \mathrm{a}$ & $0.119 \pm 0.008 \mathrm{a}$ \\
\hline & $\mathrm{A}+\mathrm{P}$ & $0.267 \pm 0.007 \mathrm{~b}$ & $0.095 \pm 0.011 b$ & $0.363 \pm 0.013 b$ & $0.74 \pm 0.08 b$ & $0.77 \pm 0.09 b c$ & $0.34 \pm 0.03 b c$ & $0.067 \pm 0.012 \mathrm{~cd}$ \\
\hline & $\mathrm{G}+\mathrm{A}+\mathrm{P}$ & $0.301 \pm 0.007 \mathrm{ab}$ & $0.139 \pm 0.006 \mathrm{ab}$ & $0.440 \pm 0.011 \mathrm{ab}$ & $0.89 \pm 0.09 \mathrm{ab}$ & $0.96 \pm 0.08 \mathrm{ab}$ & $0.41 \pm 0.01 \mathrm{ab}$ & $0.093 \pm 0.008 b$ \\
\hline \multirow{8}{*}{$\begin{array}{l}\text { High } \\
\text { concentration }\end{array}$} & Control & $0.117 \pm 0.004 \mathrm{f}$ & $0.018 \pm 0.007 \mathrm{f}$ & $0.135 \pm 0.009 \mathrm{f}$ & $0.21 \pm 0.06 f$ & $0.27 \pm 0.08 \mathrm{f}$ & $0.06 \pm 0.01 \mathrm{f}$ & $0.018 \pm 0.006 f$ \\
\hline & G.mosseae & $0.157 \pm 0.007 \mathrm{de}$ & $0.048 \pm 0.006 \mathrm{de}$ & $0.205 \pm 0.010 \mathrm{de}$ & $0.37 \pm 0.06 \mathrm{~d}$ & $0.48 \pm 0.08 \mathrm{de}$ & $0.28 \pm 0.01 \mathrm{~cd}$ & $0.046 \pm 0.008 \mathrm{de}$ \\
\hline & A. laevis & $0.153 \pm 0.008 \mathrm{de}$ & $0.038 \pm 0.007 \mathrm{de}$ & $0.202 \pm 0.032 \mathrm{de}$ & $0.33 \pm 0.07 \mathrm{de}$ & $0.42 \pm 0.08 \mathrm{de}$ & $0.24 \pm 0.01 \mathrm{~d}$ & $0.036 \pm 0.008 \mathrm{e}$ \\
\hline & $G+P$ & $0.197 \pm 0.004 \mathrm{~cd}$ & $0.067 \pm 0.007 \mathrm{~cd}$ & $0.264 \pm 0.009 \mathrm{~cd}$ & $0.55 \pm 0.08 \mathrm{c}$ & $0.59 \pm 0.08 \mathrm{~cd}$ & $0.36 \pm 0.02 b$ & $0.073 \pm 0.010 \mathrm{c}$ \\
\hline & $A+P$ & $0.161 \pm 0.004 d$ & $0.048 \pm 0.004 \mathrm{~d}$ & $0.209 \pm 0.008 \mathrm{de}$ & $0.48 \pm 0.12 \mathrm{~cd}$ & $0.54 \pm 0.09 \mathrm{~d}$ & $0.26 \pm 0.01 \mathrm{~cd}$ & $0.036 \pm 0.011 \mathrm{e}$ \\
\hline & $\mathrm{G}+\mathrm{A}+\mathrm{P}$ & $0.221 \pm 0.006 \mathrm{c}$ & $0.071 \pm 0.010 \mathrm{c}$ & $0.292 \pm 0.009 \mathrm{c}$ & $0.63 \pm 0.11 b c$ & $0.72 \pm 0.08 \mathrm{bc}$ & $0.32 \pm 0.012 \mathrm{c}$ & $0.062 \pm 0.006 b c$ \\
\hline & $\operatorname{LSD}(\mathrm{P} \leq 0.05)$ & 0.0152 & 0.0202 & 0.03 & 0.2458 & 0.2312 & 0.0352 & 0.0242 \\
\hline & $\operatorname{ANOVA}\left(\mathrm{F}_{15,32}\right)$ & 542.651 & 95.577 & 331.785 & 30.744 & 38.271 & 347.802 & 46.558 \\
\hline \multirow[t]{3}{*}{ F values } & Fertilizer (f) & 1513.755 & 185.043 & 2532.364 & 42.654 & 83.162 & 304.820 & 60.497 \\
\hline & Parameter (p) & 684.648 & 106.598 & 478.200 & 64.334 & 92.488 & 1576.740 & 132.964 \\
\hline & $\mathrm{f} \times \mathrm{p}$ & 54.934 & 23.773 & 42.596 & 7.007 & 8.681 & 11.419 & 6.735 \\
\hline
\end{tabular}

G: Glomus mosseae; A: Acaulospora laevis; P: Pseudomonas fluorescens.

\pm Standard deviation, the mean difference is significant at a 0.5 level.

Mean value followed by different letters in a column do not differ significantly according to Duncan's Multiple Range Test $(\mathrm{P} \leq 0.05)$. 
inoculated with G. mosseae, Gigaspora rosea, Glomus intraradices, and three different $\mathrm{P}$ concentrations. Glomus mosseae and A. laevis (AM fungi) also showed better results for increasing shoot and root $\mathrm{P}$ content. A significant increase in shoot $\mathrm{P}$ concentration in L. usitatissimum was also observed by Rydlová et al. (2011) when inoculated with $G$. mosseae or G. intraradices and their combination. These results confirm that root inoculation with AM fungi increases shoot and root $\mathrm{P}$ content, which will ultimately increase plant fiber content as found in the AM inoculated plant.

\section{Phosphatase activity}

We observed that phosphatase activity was greatly enhanced in inoculated plants as compared with the control (Table 2). According to Sarapatka (2003), phosphatase activity can significantly increase after applying organic manure. Phosphatase activity is also influenced by mineral fertilizers. A medium fertilizer dose stimulated phosphatase activity. The highest increase in both acidic and alkaline phosphatase activity was observed in the plants inoculated with $G$. mosseae $+P$. fluorescens $\left(0.447 \pm 0.012 \mathrm{IU} \mathrm{g}^{-1} \mathrm{FW}\right)$ and $(0.119 \pm 0.008$ IU $\left.\mathrm{g}^{-1} \mathrm{FW}\right)$, respectively, at the medium concentration where the recommended superphosphate dose was applied to the plants (Table 2). The second highest results were obtained in the G. mosseae + A. laevis + P. fluorescens $\left(0.429 \pm 0.012 \mathrm{IUg}^{-1} \mathrm{FW}\right)$ and $\left(0.101 \pm 0.010 \mathrm{IUg}^{-1} \mathrm{FW}\right)$ triple combination and followed by the double inoculation of $G$. mosseae $+P$. fluorescens $\left(0.421 \pm 0.016 \mathrm{IUg}^{-1} \mathrm{FW}\right)$ and $\left(0.098 \pm 0.009 \mathrm{IUg}^{-1} \mathrm{FW}\right)$ at the low concentration where half the recommended dose was applied to the plant. According to the result attributes (Table 2), it is clear that the high superphosphate dose (double recommended dose) causes a decrease in both acidic and alkaline phosphatase activity in L. usitatissimum. Acidic phosphatase activity was found to be higher than alkaline phosphatase activity. Plants with higher mycorrhizal root colonization had maximum phosphatase activity (alkaline and acidic). These enzymes help bound $\mathrm{P}$ mineralize into soluble forms and make it available to the plants. This $\mathrm{P}$ is then absorbed by the plants through the AM colonized roots thus absorbing maximum soil $\mathrm{P}$. The present findings agree with other numerous reports (Dodd et al., 1987; Rubio et al., 1990; Abdel-Fattah, 2001) therefore, phosphatase activity can improve soil health and also act as an indicator of soil quality.

\section{CONCLUSIONS}

The present investigation has shown that inoculating AM fungi and phosphate solubilizing bacteria P. fluorescens helps effective superphosphate use by changing it into available forms, which is later taken up by the plants for better growth and development. The current study has shown that inoculating with plant growth- promoting microorganisms (G. mosseae, A. laevis, and $P$. fluorescens) enhance the overall growth performance of L. usitatissimum plants at the recommended $\mathrm{P}$ dose level. Half the recommended superphosphate dose also triggers growth parameters in L. usitatissimum. We conclude that AM fungi and P. fluorescens are essential in flax growth at the superphosphate recommended dose or at the lower than recommended dose, which is representative of the conditions under which most flax is grown.

\section{ACKNOWLEDGEMENTS}

The authors are thankful to Kurukshetra University, Kurukshetra for providing laboratory facilities and financial assistance to carry out this research.

Influencia de hongos micorriza arbusculares y Pseudomonas fluorescens con diferentes niveles de superfosfato sobre la respuesta al crecimiento de lino (Linum usitatissimum L.). La presente investigación tuvo como objetivo estudiar la influencia de hongos micorrícicos arbusculares (AMF), i.e., Glomus mosseae (T.H. Nicolson \& Gerd.) Gerd. \& Trappey Acaulospora laevis (Gerd. \& Trappe), en la respuesta de crecimiento de lino (Linum usitatissimum L.) con bacterias solubilizantes de fosfato Pseudomonas fluorescens en presencia de diferentes dosis de superfosfato, i.e. $20 \mathrm{~kg} \mathrm{ha}^{-1}$ (mitad de la dosis recomendada), $40 \mathrm{~kg} \mathrm{ha}^{-1}$ (dosis recomendada), y $80 \mathrm{~kg} \mathrm{ha}^{-1}$ (doble de la dosis recomendada) en macetas con suelo esterilizado en condiciones de invernadero. Entre todos los parámetros de crecimiento, altura de planta $(78.74 \pm 1.8 \mathrm{~cm})$, peso fresco de brote $(3.45 \pm 0.294$ $\mathrm{g})$, peso seco de brote $(0.57 \pm 0.007 \mathrm{~g})$, peso fresco de raíz $(0.223 \pm 0.023 \mathrm{~g})$, peso seco de raíz $(0.036 \pm 0.004$ $\mathrm{g})$, longitud radical $(17.67 \pm 0.48 \mathrm{~cm})$, número de esporas de AM $(94.4 \pm 9.86)$, contenido de P de brote $(1.14 \pm$ $0.115 \%)$ y raíz $(1.29 \pm 0.110 \%)$, actividad de fosfatasa ácida $\left(0.447 \pm 0.012 \mathrm{IU} \mathrm{g}^{-1} \mathrm{FW}\right)$ y alcalina $(0.119 \pm$ $0.008 \mathrm{IU} \mathrm{g}^{-1} \mathrm{FW}$ ) fueron los más altos en combinación $G$. mosseae $+P$. fluorescens de concentración media (dosis recomendada de superfosfato); mientras la colonización micorríciza radical porcentual con combinación $A$. laevis $+P$. fluorescens $(86.86 \pm 2.17 \%)$ y contenido de clorofila con combinación $G$. mosseae + A. laevis $+P$. fluorescens $\left(0.474 \pm 0.009 \mathrm{mg} \mathrm{g}^{-1} \mathrm{FW}\right)$ fue la más alta a menor concentración (mitad de la dosis recomendada de superfosfato) en comparación con plantas sin micorrizas (control). Dosis mayores de superfosfato redujeron todos los parámetros de crecimiento. Así, puede lograrse crecimiento vigoroso y producción máxima de lino al inocular las plantas con hongos AM y P. fluorescens junto con dosis recomendada o inferior a la dosis recomendada para superfosfato.

Palabras clave: Linum usitatissimum, hongos AM, Pseudomonas fluorescens, absorción de P, actividad de P. 


\section{LITERATURE CITED}

Abdel-Fattah, G.M. 2001. Measurement of the viability of arbuscularmycorrhizal fungi using three different stains; relation to growth and metabolic activities of soybean plants. Microbiological Research 156:359-367.

Ali, A., M. Hussain, A. Tanveer, M.A. Nadeem, and L. Haq. 2002. Effect of different levels of phosphorus on seed and oil yield of two genotypes of linseed (Linum usitatissimum L.) Pakistan Journal of Agriculture 39(4):281-282.

Arnon, D.T. 1949. Copper enzyme in isolated chloroplasts polyphenol oxidase in Beta vulgaris. Plant Physiology 24:1-5.

Berti, M., S. Fischer, R. Wilckens, and F. Hevia. 2009. Flaxseed response to N, P and $\mathrm{K}$ fertilization in South Central Chile. Chilean Journal of Agricultural Research 69:145-153.

Bhatt Nikhil, S., A. Sherasiya, D.S. Murty, and N.S. Junnarkar. 2011. Interrelationship between alkaline phosphatse activity and soil characteristics. Bioscience Guardian 1:473-480.

Cavagnaro, T.R., F.A. Smith, S.E. Smith, and I. Jakobsen. 2005. Functional diversity in arbuscular mycorrhizas: exploitation of soil patches with different phosphate enrichment differs among fungal species. Plant, Cell \& Environment 28:642-650.

Charlton, B., and D. Ehrensing. 2001. Fiber and oilseed flax performance. Annual report. Oregon State University, Corvallis, Oregon, USA.

Davis, R.M., J.A. Menge, and D.C. Erwin. 1979. Influence of Glomus fasciculatus and soil phosphorus on Verticillium wilt of cotton. Ecology and Epidemiology 69:453-456.

Dodd, J.C., C.C. Burton, R.G. Burns, and P. Jeffries. 1987. Phosphatase activity associated with the roots and the rhizosphere of plants infected with vesicular-arbuscular mycorrhizal fungi. New Phytologist 107:163-172.

Eichler, B., M. Caus, and E. Schnug. 2004. Soil acid and alkaline phosphatases activities in regulation to crop species and fungal treatment. Landbauforschung Völkenrode 54:1-5.

Gaur, A., and A. Adholeya. 1994. Estimation of VAM fungal spores in soil: A modified method. Mycorrhiza News 6:10-11.

Gerdemann, J.W., and Y.H. Nicolson. 1963. Spores of mycorrhizal Endogone species extracted from soil by wet sieving and decanting. Transactions of British Mycological Society 46:235244.

Jackson, M.L. 1973. Soil chemical analysis. 485 p. Prentice Hall, New Delhi, India.

Mangla, C., A. Kumar, and A. Aggarwal. 2010. Inoculum production of Arbuscular mycorrhizal fungi using paper-mill solid waste as substrate. Journal of Indian Botanical Society 89:133-137.

Metrycki, B. 2004. Making the flax-linoleum connection. Flax Focus 17:4-5.

Morton, J.B., and G.L. Benny. 1990. Revised classification of arbuscular mycorrhizal fungi (Zygomycetes): A new order, Glomales, two new suborders, Glomineae and Gigasporineae, and two new families, Acaulosporaceae and Gigasporaceae, with an emendation of Glomaceae. Mycotaxon 37:471-491.

Mukerji, K.G. 1996. Taxonomy of endomycorrhizal fungi. p. 211221. In Mukerji, K.G., B. Mathur, B.P.Chamola, and P. Chitralekha (eds.) Advances in botany. APH Publishing Corporation, New Delhi, India.

Nagarajan, G., and A. Mahadevan. 2002. Effect of arbuscular mycorrhizal fungi on growth and yield of sunflower. p. 231237. In Manoharachary, C., D.K. Purohit, S. Ram Reddy, M.A. Singara Charya, and S. Girisham (eds.) Frontiers in microbial biotechnology and plant pathology. Scientific Publishers, Jodhpur, India.

Neetu, A. Tanwar, and A. Aggarwal. 2011. Impact of arbuscular mycorrhizal fungi and other bioinoculants on growth promotion in Linum usitatissimum L. Journal of Indian Botanical Society 90:216-223.

O’Sullivan, D.J., and F. O'Gara. 1992. Traits of fluorescent Pseudomonas spp. involved in suppression of plant root pathogens. Microbiological Reviews 56:662-676.

Pasqualini, D., A. Uhlmann, and S.L. Stürmer. 2007. Arbuscular mycorrhizal fungal communities influence growth and phosphorus concentration of woody plants species from the Atlantic rain forest in South Brazil. Forest Ecology and Management 245:148-155.

Phillips, J.M., and D.S. Hayman. 1970. Improved procedures for clearing roots and staining parasitic and VAM fungi for rapid assessment of infection. Transactions of British Mycological Society 55:158-161.

Prasad, K., and R.S. Bilgrami. 2002. Impact of Glomusfasciculatum (VAM) and phosphates on biomass yield and chlorophyll contents of Saccharum officinarum L. p. 53-60. In Reddy, S.M., S.R. Reddy, M.A. Singarachary, and S. Grisham (eds.) Bioinoculants for sustainable agriculture and forestry. Scientific Publishers, Jodhpur, India.

Rubio, R., E. Moraga, and F. Borie. 1990. Acid phosphatase activity and vesicular-arbuscular mycorrhizal infection associated with roots of 4 wheat cultivars. Journalof Plant Nutrition 13:585-598.

Rydlová, J., D. Püschel, R. Sudová, M. Gryndler, O. Mikanová, and M. Vosátka. 2011. Interaction of arbuscular mycorrhizal fungi and rhizobia: Effects on flax yield in spoil-bank clay. Journal of Plant Nutrition and Soil Science 174:128-134.

Saleem, M.F., A. Shakeel, M.F. Bilal, M.Q. Shahid, and S.A. Anjum. 2010. Effect of different phosphorus levels on earliness and yield of cotton cultivars. Soil \& Environment 29:128-135.

Sanders, F.E., and P.B. Tinker. 1973. Phosphate inflow in mycorrhizal roots. Pesticide Science 4:385-395.

Sarapatka, B. 2003. Phosphatase activities (ACP, ALP) in agroecosystem soils. $\mathrm{PhD}$ thesis. Swedish University of Agricultural Sciences, Uppsala, Sweden.

Schenck, N.C., and Y. Perez. 1990. Manual for the identification of VA mycorrhizal VAM fungi. 241 p. University Press of Florida, Gainesville, Florida, USA.

Sharma, A.D., M. Thakur, and M. Rana. 2004. Effect of plant growth hormones and abiotic stresses on germination, growth and phosphatase activities in Sorghum bicolor L. Moench seeds. African Journal of Biotechnology 3:308-312.

Shibata, R., and K. Yano. 2003. Phosphorus acquisition from non-labile sources in peanut and pigeon pea with mycorrhizal interaction. Applied Soil Ecology 24:133-141.

Sridevi, S., and K. Ramakrishnan. 2010. The effect of NPK fertilizer and AM fungi on the growth and yield of cotton (Gossypium hirsutum L.) var. LRA 5166. Recent Research in Science and Technology 2(10):39-41.

Supatra, S., and S. Mukherji. 2004. Alterations in activities of acid phosphatase, alkaline phosphatase, ATPase and ATP content in response to seasonally varying Pi status in Okra (Abelmoschus esculentus). Journal of Environmental Biology 25:181-185.

Tabatabai, M.A., and J.M. Bremner. 1969. Use of p-nitrophenol for assay of soil phosphatse activity. Soil Biology and Biochemistry 1:301-307.

Thingstrup, I., G. Rubaek, E. Sibbesen, and I. Jakobsen. 1998. Flax (Linum usitatissimum L.) depends on arbuscular mycorrhizal fungi for growth and $\mathrm{P}$ uptake at intermediate but not high soil $\mathrm{P}$ levels in the field. Plant and Soil 203:37-46.

Torrisi, V., G.S. Pattinson, and P.A. McGee. 1999. Localized elongation of roots of cotton follows establishment of arbuscular mycorrhizas. New Phytologist 142:103-112.

Walker, C. 1983. Taxonomic concepts in the Endogonaceae spore wall characteristics in species description. Mycotaxon 18:443445 . 